\title{
Phenoloxidase activity and haemolymph cytology in honeybees challenged with a virus suspension (deformed wings virus DWV) or phosphate buffered suspension (PBS)
}

\author{
Francesca Millanta ${ }^{1}$ iD Simona Sagona ${ }^{1,2}$ iD Maurizio Mazzei ${ }^{1}$ iD Mario Forzan $^{1}$ iD \\ Alessandro Poli ${ }^{1}$ iD Antonio Felicioli ${ }^{1 *}$ id
}

${ }^{1}$ Department of Veterinary Science, University of Pisa, 56124, Pisa, Italy. E-mail: antonio.felicioli@unipi.it. "Corresponding author. ${ }^{2}$ Department of Pharmacy, University of Pisa, Pisa, Italy.

ABSTRACT: The innate immune system of honeybees mainly consists in antimicrobial peptides, cellular immunity and melanisation. In order to investigate the immune response of honeybees to immune stressors, three stress degrees were tested. Newly emerged bees naturally $D W V$-infected were collected from a Varroa mite-free apiary and divided into three experimental groups: naturally DWV infected bees, PBS injected bees, and artificially DWV super infected bees. Phenoloxidase activity and haemolymph cellular subtype count were investigated. Phenoloxidase activity was highest $(P<0.05)$ in DWV-superinfected bees, and the haemocyte population differed within the three observed groups. Although, immune responses following DWV infection have still not been completely clarified, this investigation sheds light on the relation between cell immunity and the phenoloxidase activity of DWV-naturally infected honeybees exposed to additional stress such as injury and viral superinfection.

Key words: cellular immunity, phenoloxidase, honeybees, DWV, haemocytes.

Atividade fenoloxidase e citologia de hemolinfa em abelhas infectadas com uma suspensão de vírus (DWV deformed wings) ou suspensão tamponada com fosfato (PBS)

RESUMO: O sistema imune inato das abelhas consiste principalmente em peptídeos antimicrobianos, imunidade celular e melanização. Para investigar a resposta imune das abelhas a estressores imunológicos, foram testados três graus de estresse. Abelhas recém-emergidas naturalmente infectadas por DWV foram coletadas de um apiário livre de Varroa e divididas em três grupos experimentais: abelhas naturalmente infectadas por DWV, abelhas injetadas com PBS e abelhas superinfectadas artificialmente com DWV. A atividade de fenoloxidase $e$ a contagem de subtipos celulares de hemolinfa foram investigadas. A atividade da fenoloxidase foi maior $(P<0,05)$ nas abelhas superinfectadas com $D W V$, e a população de hemócitos diferiu entre os três grupos observados. Embora as respostas imunes após a infecção pelo DWV ainda não tenham sido completamente esclarecidas, esta investigação lança luz sobre a relação entre a imunidade celular e a atividade da fenoloxidase das abelhas infectadas naturalmente pelo DWV, expostas a estresse adicional, como lesão e superinfecção viral.

Palavras-chave: immunidade celular, fenoloxidase, abelha, DWV, emocytes, infecção viral.

\section{INTRODUCTION}

Honeybees are social insects and their complex defence mechanisms are structured at social and individual levels (CREMER et al., 2007). Social innate immune defence is a complex and structured system characterized by the specific hygienic behaviour of honeybees (WILSON-RICH et al., 2009; ALAUX et al., 2010). Furthermore, the glucose oxidase is an enzyme that contributes to the social immunity with its involvement in both gluconic acid and peroxide hydrogen productions (LÓPEZ-URIBE et al., 2017). The individual innate immune system consists in a wide variety of highly effective innate defence pathways based on humoral and cellular responses, such as phagocytosis, nodule formation and encapsulation mediated by melanisation (SCHMID et al., 2008; WILSON-RICH et al., 2009). Within these defence mechanisms, phenoloxidase (PO) is a key enzyme responsible for melanin production (SCHMID-HEMPEL, 2005; SIVA-JOTHY et al., 2005). Phenoloxidase is present in the haemolymph as pro-phenoloxidase and is activated by a serine proteinase (NAKHLEH et al., 2017). The PO cascade can be activated by some molecules such as lipopolysaccharides, $\beta$-glucans and peptidoglycans as observed also in recent studies focused on the effect of these molecules on both phenoloxidase activity and haemocytes populations (CHARLES \& KILLIAN, 2015; MAZZEI et al., 2016; NAKHLEH, 2017; 
SHEEHAN, 2018). Prohaemocytes, plasmatocytes (round, oval, irregular), granulocytes and oenocytoids are all included in the term "haemocytes" (ELMOHANDES et al., 2010; SABCALIU et al., 2010). Haemocytes are cell types responsible for the honeybees' defence against pathogens. Within the differentiated haemocytes, granulocytes play a role in phagocytosis and encapsulation, and plasmatocytes tend to proliferate after contact with antigens and are capable of acting as phagocytes (SIVA-JOTHY et al., 2005). Haemocytes population decreases as consequence of pollen diet administration while a protein-free diet determines an increase of haemocytes number (SZYMAŚ, B.; JĘDRUSZUK, 2003; BRODSCHNEIDER \& CRAILSHEIM, 2010). Both haemocytes and phenoloxidase are involved in the wound healing (KRAUTZ et al., 2014; DUBOVSKIY, 2016).

Immune stressors such as pathogen infection continuously stimulate the honeybees' humoral and cellular systems (NAZZI \& PENNACCHIO, 2014). Among honeybee pathogens, deformed wing virus (DWV) is a widespread honeybee virus transmitted by Varroa destructor, an ectoparasitic honey bee mite (FRANCIS et al., 2013). Asymptomatic honeybees are commonly reported worldwide with low DWV titers, while symptomatic DWV honeybees show a high titer infection and die prematurely showing deformed wings, inability to fly, and a shortened abdomen (DE MIRANDA \& GENERSCH, 2010).

The aim of this study was to investigate the PO activity and to characterise the haemocyte population in bees exposed to different stress conditions: following either needle injury or DWV superinfection. Although, honeybees involved in this research were previously studied in a parallel investigation to assess the role of $\beta$-glucans as immune modulators (MAZZEI et al., 2016), the present study focuses on the humoral and cellular responses to pathological stimuli, without the interference of immunomodulatory agents.

\section{MATERIALS AND METHODS}

\section{Honeybee rearing conditions}

Newly-emerged honeybees were collected on the isle of Gorgona, from a Varroa mite-free experimental apiary (GIUSTI et al., 2016), and divided in 3 groups of 3 experimental cages each. Cages contained 30 honeybees each. All groups were fed a syrup-based diet (Fruttosweet 45, A.D.E.A, Varese, Italy). All honeybees were reared under the same conditions for five days. At days 0 and 6 prior to setting up the experimental groups, fifteen honeybees were sacrificed and stored at $-20^{\circ} \mathrm{C}$ for the PO assay. At day 6, honeybees were treated as follows: honeybees from 3 cages were reared with no treatment and defined as the control group (DWV naturally infected); honeybees constituting 3 cages were given PBS injection (PBS injected); and finally, honeybees from three cages were subjected to DWV superinfection (artificially DWV injected with high titer DWV suspension).

By using honeybees with overt DWV infection a high titer DWV suspension $\left(5 \times 10^{8}\right.$ copies $\mathrm{DWV} / \mu \mathrm{l})$ was prepared, according to MAZZEI et al. (2014). The PBS or DWV suspensions were injected into the thorax haemolymph using a volume of $2.5 \mu \mathrm{l}$. At day 13 of rearing, all surviving honeybees were sacrificed following $\mathrm{CO}_{2}$ inhalation and processed for final analysis.

\section{DWV analysis}

At day 13 of rearing, thirty-six honeybees belonging to each group were sacrificed and subjected to total RNA extraction. RNAwas quantified and subjected to qRT-PCR absolute quantification assay as described in MAZZEI et al. (2014). Briefly, a one-step real time assay was applied for the absolute quantification of DWV RNA performed with Quantitect Probe RT PCR Kit (Qiagen, Hilden, Germany) using a Rotorgene Corbett 6000 (Corbett Research, Sydney, Australia). All reactions were carried out in duplicate, in a volume of $25 \mu \mathrm{l}$, with $5 \mu \mathrm{l}$ of extracted RNA. Primers amplified a $132 \mathrm{bp}$ fragment within the highly conserved region coding for Rd-Rp. The sequences were: DWV Fw 5'TTTGACATTGAGCTACAAGACTCG-3', DWV Rev 5'- ACAATCCGTGAATATAGTGTGAGG-3' and DWV probe Fw 5'- [6FAM] TCTCCTGCGTGGAATGCGTCCCGA [BHQ1]-3'. The total viral load of each honeybee was calculated considering qRT-PCR values obtained from the abdomen and head normalized to $\mathrm{mg}$ of tissue. Viral load was expressed as viral copy number/bee.

\section{Phenoloxidase activity}

Phenoloxidase activity was assayed from protein extracts obtained from the head and abdomen of each honeybee. Samples were composed by 45 bees sampled at T0, T6 and T13 for the control group, and 15 for other experimental groups (only T13, because the experimental infection was performed at $6^{\text {th }}$ day of rearing). Each head was soaked in $200 \mu$ of $50 \mathrm{mM}$ PBS, $1 \%$ Triton $\mathrm{X}-100$, incubated at $-20^{\circ} \mathrm{C}$ for $20 \mathrm{~min}$, homogenized, and centrifuged at $1075 \mathrm{~g}$ at $4^{\circ} \mathrm{C}$ for $15 \mathrm{~min}$. The supernatant was collected and the pellet was suspended in $200 \mu 1$ of $50 \mathrm{mM}$ PBS and centrifuged 
as above. Enzymatic activity was determined on $50 \mu 1$ of extract per analysis, using melanin for the calibration curve according to ALAUX et al. (2010). Results were expressed as $\mathrm{mUE} / \mathrm{min} / \mathrm{mg}$ of tissue.

\section{Haemocyte analysis}

Thirteen day-old bees were sampled from the control group, the PBS injected group and the DWV superinfected group, ( $\mathrm{n}=7$ per group). Honeybees were anesthetized by $\mathrm{CO}_{2}$ inhalation, and a glass capillary was introduced in the sinus dorsalis, between the third and fourth abdominal segment. A microliter of haemolymph was dropped onto a clean microscope slide, smeared and immediately stained with Difstain kit (TitolChimica, Rovigo, Italy). Cytologic examination was performed by optic microscopy (magnification 40X and 100X). Haemocytes were classified and quantified based on their morphology as prohaemocytes, plasmatocytes (round, oval, irregular), granulocytes and oenocytoids (EL-MOHANDES et al., 2010; SABCALIU et al., 2010).

\section{Statistical analysis}

Statistical analysis was performed using JMP software (SAS Institute, 2008). Differences between groups were analysed for DWV viral load and phenoloxidase activity with non-parametric
Kruskal-Wallis tests (Rank Sums). When significant differences were found between factors, means were ordered and differences were again tested with a non-parametric Kruskal-Wallis test. The haemocyte populations were compared by Cochran-MantelHaenszel test (DAY \& BYAR, 1979).

$$
\text { P-values }<0.05 \text { were considered }
$$
statistically significant.

\section{RESULTS}

\section{DWV analysis}

The DWV viral load analysis showed a significant difference among naturally (control bees) and superinfected groups $(\mathrm{P}<0.0001)$. At day 13 of rearing, all honeybees subjected to DWV superinfection scored viral loads over seven orders of magnitude greater than the naturally infected groups, thus highlighting effectiveness of the injection and the viability of the viral suspension used (Figure 1).

\section{Phenoloxidase activity}

In Figure 2 is reported the phenoloxidase activity ( $\mathrm{mUE} / \mathrm{min} / \mathrm{mg}$ of tissue) in the honeybee samples from the control group at three time points: at the time of the honeybee collection from the hive

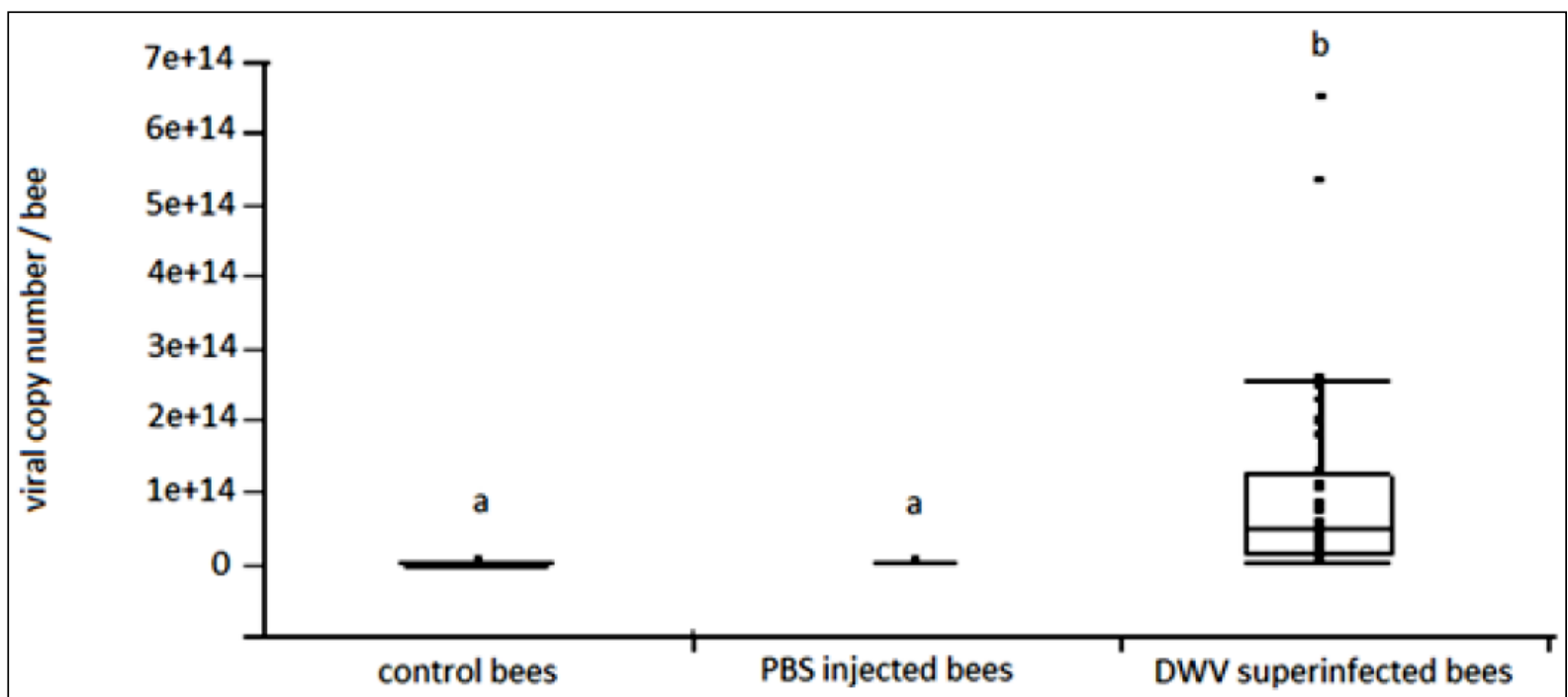

Figure 1 - Box plot representing viral copy number per bee in each experimental group. The total viral load of each honeybee was calculated considering qRT-PCR values obtained from the abdomen and head normalised to mg of tissue. Different letters show statistically significant differences $(\mathrm{P}<0.0001)$. 


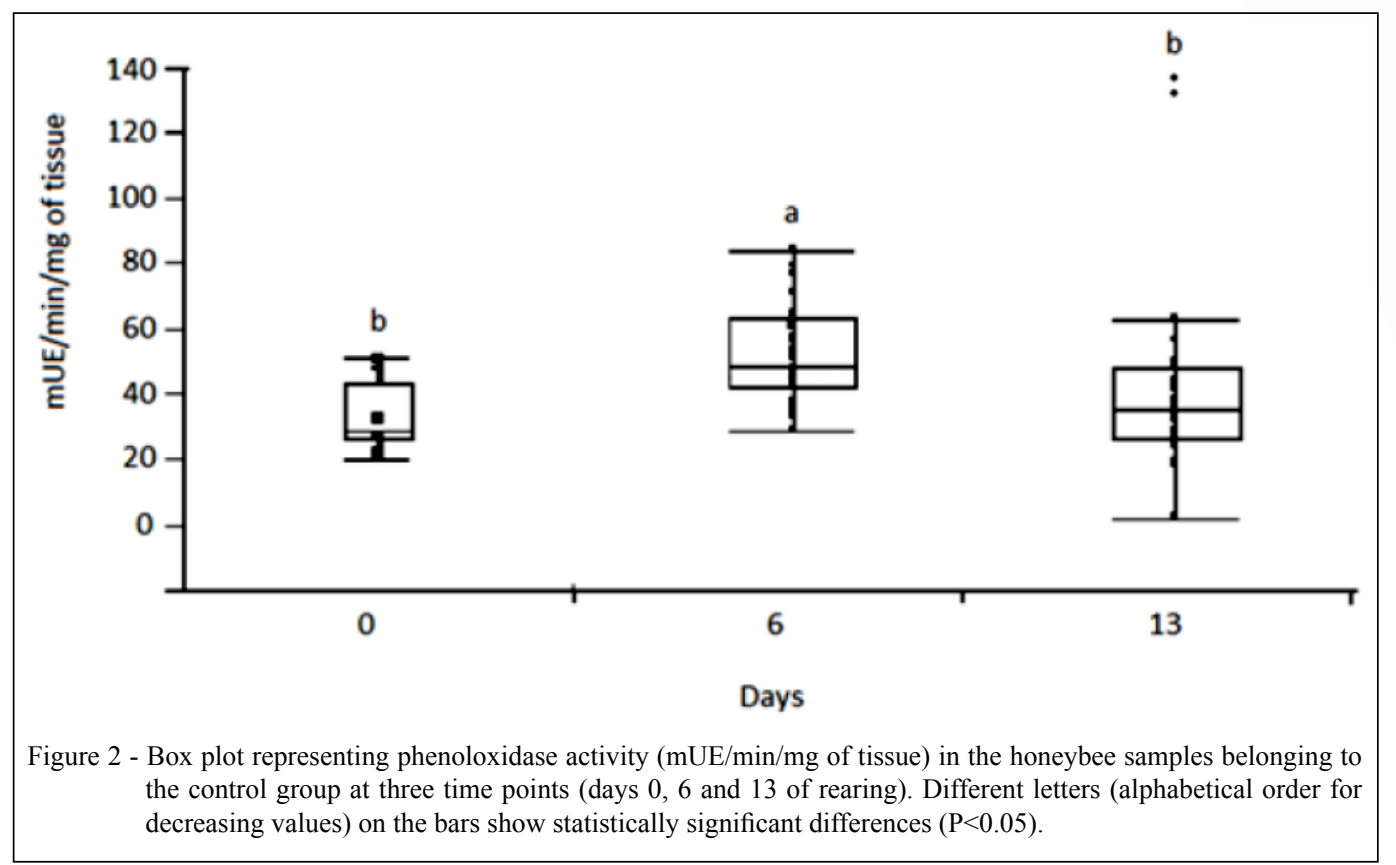

(day $0, \mathrm{~T}_{0}$ ), on the day of the DWV infection or PBS injection (day 6 of rearing), and on the last day of rearing (day 13). Honeybees belonging to the control group showed a significant increase in PO activity at day 6 and a significant decrease at day 13 compared to $\mathrm{T}_{0}(\mathrm{P}<0.001$ and $\mathrm{P}<0.005$ respectively) (Figure 2 ).
At day 13, experimental groups showed significant differences in $\mathrm{PO}$ activity $(\mathrm{P}<0.05)$; the highest phenoloxidase activity was observed for the DWV superinfected group $(52.2 \pm 4.3 \mathrm{mUE} / \mathrm{min} / \mathrm{mg}$ of tissue), while the lowest was observed for the PBS injected bees (41.2 $\pm 2.1 \mathrm{mUE} / \mathrm{min} / \mathrm{mg}$ of tissue) (Figure 3 ).

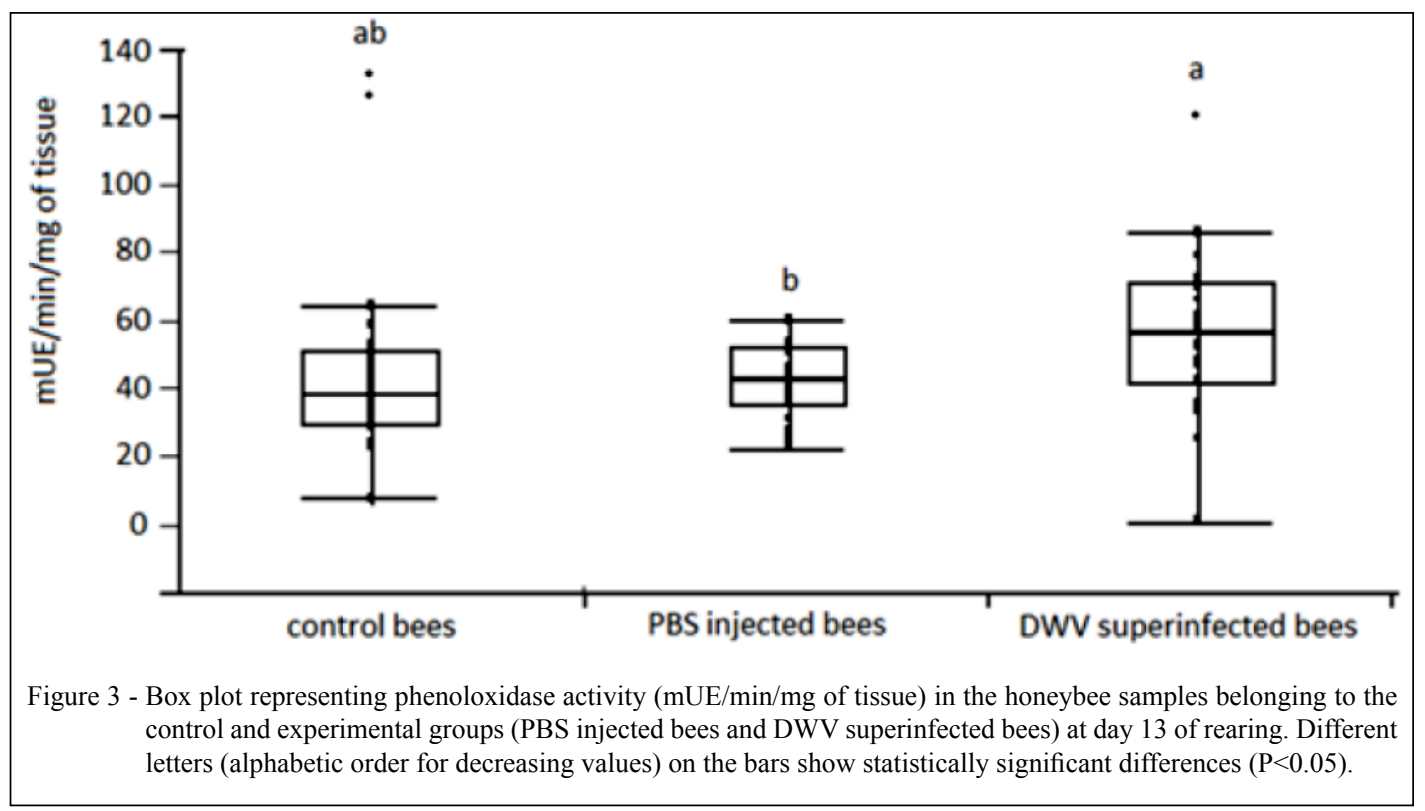

Ciência Rural, v.49, n.2, 2019. 


\section{Haemocyte analysis \\ Cytologic smears from haemolymph} samples showed the presence of different plasmatocyte populations (Figure 4). Significant differences were reported by analyzing the total haemolymph cellular populations by Cochran-Mantel-Haenszel test. The haemocytes' population belonging to the control bees resulted overall statistically different compared to those belonging to PBS injected bees and DWV superinfected bees $(\mathrm{P}<0.01)$ The haemocytes' population belonging to PBS injected bees and DWV superinfected bees were not statistically different if compared by Cochran-Mantel-Haenszel test $(\mathrm{P}>0.05)$.

Table 1 are reported the mean percentages among the replicates of each cell type identified within the haemocyte population of each experimental group. The highest concentration of granulocytes was observed in the control bees (median $2, \min 0, \max 7$ ). The oenocytoides were observed in the control bees and DWV superinfected bees, but were not detected in the PBS injected bees.

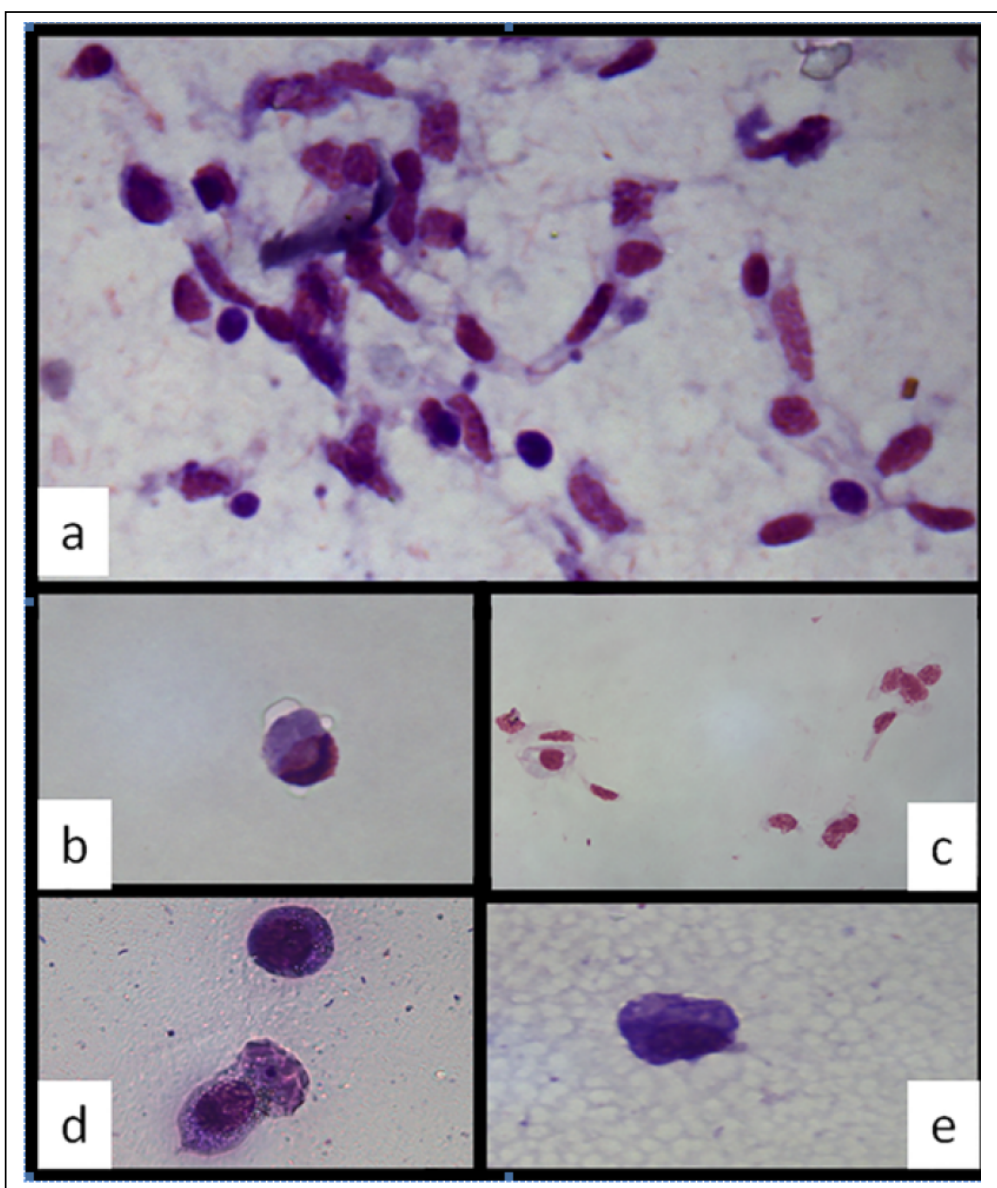

Figure 4A - Cytologic smears from haemolymph showing several plasmatocytes and small, round prohaemocytes (Dif-stain kit, 40X magnification). B: A round-shaped prohemocyte with a prominent nucleus and a scant amount of basophilic cytoplasm (Dif-stain kit, 100X magnification. C: Plasmatocytes showing round, oval to spindle and irregular shapes (Dif-stain kit, 25X magnification). D: Granulocytes showing a round, centrally located nucleus and granular cytoplasm (Dif-stain kit, 100X magnification). E: A voluminous oenocytoid with intensely basophilic cytoplasm and oval and hyperchromatic nucleus (Dif-stain kit, 40x magnification). 
Table 1 - Percentage of different haemocytes from honeybees belonging to three experimental groups (Control bees, PBS injected bees and DWV superinfected bees). Results are expressed as median (minimum - maximum), $\mathrm{n}=7$ for each group.

\begin{tabular}{lccc}
\hline Haemocyte type & Control bees & PBS injected bees & DWV superinfected bees \\
\hline Prohaemocytes & $25(8-39)$ & $18(12-40)$ & $30(11-80)$ \\
Round plasmatocytes & $8(3-13)$ & $6(0-7)$ & $13(2-18)$ \\
Oval plasmatocytes & $19(3-40)$ & $21(6-41)$ & $51(1-70)$ \\
Irregular plasmatocytes & $19(0-31)$ & $10(0-34)$ & $10(0-32)$ \\
Total plasmatocytes & $46(6-84)$ & $29(10-81)$ & $80(8-98)$ \\
Granulocytes & $2(0-7)$ & $0(0-2)$ & $0(0-2)$ \\
Oenocytoids & $0(0-1)$ & $0(0-0)$ & $0(0-1)$ \\
\hline
\end{tabular}

\section{DISCUSSION}

The aim of this study was to investigate innate immunity aspects in DWV naturally-infected honeybees. This was achieved by measuring and comparing the PO activity and the composition of haemocyte subtypes among bees exposed to different stress conditions. Both phenoloxidase activity and haemocyte population patterns have been described by previous studies in relation to age, rearing condition, and nutrition (SZYMAŚ \& JĘDRUSZUK, 2003; ZUFELATO et al., 2004; SCHMID et al., 2008). Phenoloxidase activity increases with age, reaching a plateau within the first week as imago (SCHMID et al., 2008). Despite the increase in worker bees' phenoloxidase activity, many authors (SCHMID et al., 2008; LAUGHTON et al., 2011) have recorded a decrease in haemocyte count due to apoptosis with the transition from hive bee to forager, which should consequently reduce the level of cellular immune response. Although, the steady rearing conditions and feeding with commercial syrup enabled the experimental conditions to be standardized, they differ from the natural conditions (flight and diet) involved in physiological processes. Nutrition is a critical factor in immune responses (HAYDAK, 1970; BRODSCHNEIDER \& CRAILSHEIM, 2010). Effects of diet on the haemocyte type have been already described by SZYMAŚ \& JĘDRUSZUK (2003), who reported an increase in granular haemocytes, a significant decrease in other cellular types, and a lower metabolic activity in honeybees fed with a non-proteinaceous diet. DI PASQUALE et al. (2013) also observed irrelevant differences in phenoloxidase activity in honeybees fed with syrup only compared to honeybees fed with syrup and pollen. Although, in our experiment, age, rearing and nutrition were shared by all individuals, needle puncture injury, and DWV superinfection were performed on only two experimental groups.

The needle puncture injury can be considered as a time limited stress factor, and the DWV superinfection as a permanent stress condition throughout the experimental period. Our results highlighted significant differences in PO activity among the stressed groups, confirming PO modulation as a consequence of stress factors. Preliminary results indicated that were no differences when using head or abdomen as template; therefore, the head was the sample used for the assay. The lowest PO levels were recorded in the PBS injected group, and the highest in the DWV superinfected honeybees. The lowest PO activity following PBS injection may be due to the rapid use of phenoloxidase in the later stage of wound closure, when the clot is established in order to produce an impermeable physical barrier (LAUGHTON et al., 2011). The additional stress factor was represented by DWV superinfection. Viral infections induce unspecific cell defence reactions such as phagocytosis and nodule formation although, these processes are not always effective in preventing and controlling viral diseases (GLIŃSKI \& JAROSZ, 2001).

Our results showed the highest phenoloxidase activity in the DWV superinfected bees compared to the other experimental groups. The PO result is in line with the stress time duration, confirming that superinfection is a continuous stress condition affecting the progressive activation of $\mathrm{PO}$ synthesis mechanisms.

Concerning the analysis of the haemocytes pattern, our results showed that the control group differed significantly from the stressed groups, and 
no differences were recorded between PBS injured and superinfected honeybees. This evidence differs from the PO data; however, the result is probably linked to the type of parameters considered. In fact, $\mathrm{PO}$ activity is an enzymatic measurable factor whose presence is limited in time. Conversely, cellular pattern modification is more durable and effects may be observable up to seven days after the stressful event.

Haemocytes are involved in clot production and in the defence activities such as the synthesis of phenoloxidase, nitric oxide, and aggregation protein (hemokinin) (SIVA-JOTHY et al., 2005; NEGRI et al., 2014; NEGRI et al., 2016). Plasmatocytes and prohaemocytes were the most represented cell subtypes in all the groups with values of around $65 \%$ for plasmatocytes and $35 \%$ for prohaemocytes, in line with several authors (VAN WETTERE \& LEWBART, 2007; EL-MOHANDES et al., 2010).

Our results are not in agreement with those reported by SABCALIU et al. (2010) who described an increase in the plasmatocytes count from honeybees reared in stressful conditions. Our results indicated that in PBS injected and DWV superinfected bees, prohaemocytes and plasmatocytes were the most represented cell type, while a small percentage of granulocytes were recorded only in the control bees. It could be hypothesised that the cause of the presence of granulocytes in the control bees compared to other treatments, was due to the synthesis of bioactive compounds, which were depleted in the other treatments (SIVA-JOTHY et al., 2005).

Among the other cell types, a few oenocytoids were observed only in two groups (control bees and DWV infected bees) and were totally absent in PBS injected bees. The oenocytoids containing cytoplasmic precursors of phenoloxidase were not recorded in PBS injected bees, which is the group with the lowest phenoloxidase activity, thus confirming their role in PO production (LAVINE \& STRAND, 2002). Results thus suggested that a time-limited stress has effect on both the lowest PO activity and type of haemocytes, while permanent stress conditions may lead to the highest PO activity and a higher number of specialised cells.

In conclusion, our results confirmed the effects of stressful events on immune response, shedding light on the relation between cell immunity and phenoloxidase activity. Although, mechanisms of phenoloxidase activation are still not completely understood, our results highlighted the effectiveness of PO measurements and cellular pattern analyses as early and late stress indicators.

\section{ACKNOWLEDGMENTS}

This research was supported by a grant from the University of Pisa (PRA 2015 n. 0053).

\section{BIOETHICS AND COMMITTEE APPROVAL}

BIOSECURITY

We authors of the article entitled "Phenoloxidase activity and haemolymph cytology in honeybee challenged with a virus suspension (deformed wings virus DWV) or phosphate buffered suspension (PBS)" declared, for all due purposes, the project that gave rise to the present data has not been submitted for evaluation to the Ethics Committee of the University /Research Institute "Pisa University", but we are aware of the content of the Brazilian resolutions of the National Council for Control of Animal Experimentation - CONCEA "http://www.mct.gov.br/index.php/ content/view/310553.html" if it involves animals.

Thus, the authors assume full responsibility for the presented data and are available for possible questions, should they be required by the competent authorities.

\section{DECLARATION OF CONFLICTING INTERESTS}

The authors declare no conflict of interest. The founding sponsors had no role in the design of the study; in the collection, analyses, or interpretation of data; in the writing of the manuscript, and in the decision to publish the results.

\section{AUTHORS' CONTRIBUTIONS}

All authors contributed equally for the conception and writing of the manuscript. All authors critically revised the manuscript and approved of the final version.

\section{REFERENCES}

ALAUX, C. et al. Diet effects on honeybee immunocompetence. Biology Letters, v.6, p.562-565, 2010. Available from: <https://doi.org/10.1098/ rsbl.2009.0986>. Accessed: Dec. 02, 2018. doi: 10.1098/rsbl.2009.0986.

BRODSCHNEIDER, R.; CRAILSHEIM, K. Nutrition and health in honey bees. Apidologie, v.41, p.278-294, 2010. Available from: $<$ https://www.apidologie.org/articles/apido/pdf/2010/03/m09120. pdf>. Accessed: Dec. 02, 2018. doi: 10.1051/apido/2010012.

CHARLES, H.M.; KILLIAN, K.A. Response of the insect immune system to three different immune challenges. Journal of insect physiology, v.81, p.97-108, 2015. Available from: <https://doi. org/10.1016/j.jinsphys.2015.07.005>. Accessed: Dec. 02, 2018. doi: 10.1016/j.jinsphys.2015.07.005.

CREMER, S. et al. Social immunity. Current Biology, v.17, p.R693-R702, 2007. Available from: <https://doi.org/10.1016/j. cub.2007.06.008>. Accessed: Dec. 02, 2018. doi: 10.1016/j. cub.2007.06.008.

DAY, N.E.; BYAR, D.P. Testing Hypotheses in Case-Control Studies-Equivalence of Mantel-Haenszel Statistics and Logit Score Tests. Biometrics, v.35, p.623-630, 1979. Available from: <https:// www.jstor.org/stable/pdf/2530253.pdf>. Accessed: Dec. 02, 2018. 
DE MIRANDA, J.R.; GENERSCH, E. Deformed wing virus. Journal of invertebrate pathology, Suppl 1, p.48-61, 2010 Available from: <https://doi.org/10.1016/j.jip.2009.06.012>. Accessed: Dec. 02, 2018. doi: 10.1016/j.jip.2009.06.012.

DI PASQUALE, G. et al. Influence of Pollen Nutrition on Honey Bee Health. Do Pollen Quality and Diversity Matter? PLoS one, v.8, e72016, 2013. Available from: <https://doi.org/10.1371/ journal.pone.0072016>. Accessed: Dec. 02, 2018. doi: 10.1371/ journal.pone.0072016.

DUBOVSKIY, I.M. et al. Encapsulation and nodulation in insects Invertebrate Survival Journal, v.13, p.229-246, 2016. Available from: <http://www.isj.unimo.it/articoli/ISJ428.pdf>. Accessed: Dec. $02,2018$.

EL-MOHANDES, S.S. et al. Effect of different feeding diets on the haemolymph of the newly emerged honeybee workers Apis mellifera L. Egyptian Academic Journal of Biological Sciences, v.3, p.213-220, 2010. Available from: <http://eajbsa.journals.ekb eg/article_15257.html>. Accessed: Dec. 02, 2018. doi: 10.21608/ EAJBSA.2010.15257.

FRANCIS, R.M. et al. Varroa-virus interaction in collapsing honey bee colonies. PLoS one, v.8, e57540, 2013. Available from: $<$ https://doi.org/10.1371/journal.pone.0057540>. Accessed: Dec. 02, 2018. doi: 10.1371/journal.pone.0057540.

GIUSTI, M. et al. Scientific note: Varroa mite eradication, the strange case of Gorgona island. Apidologie, v.47, p.688-690, 2016. Available from: <https://link.springer.com/article/10.1007/ s13592-015-0417-3>. Accessed: Dec. 02, 2018. doi: 10.1007/ s13592-015-0417-3.

GLIŃSKI, Z.; JAROSZ, J. Infection and immunity in the honey bee, Apis mellifera L. Apiacta, v.36, p.12-24, 2001. Available from: $<$ http://www.fiitea.org/cgi-bin/index.cgi>. Accessed: Dec. 02, 2018.

HAYDAK, M.H. Honey bee nutrition. Annual review of entomology, v.15, p.143-156, 1970. Available from: $<$ http://194.47.52.113/janlars/partnerskapalnarp/ekonf/20130516/ Haydak1970.pdf>. Accessed: Dec. 02, 2018.

KRAUTZ, R.; AREFIN, B.; THEOPOLD, U. Damage signals in the insect immune response. Frontiers in plant science, v.5, p. 342 , 2014. Available from: <https://doi.org/10.3389/fpls.2014.00342>. Accessed: Dec. 02, 2018. doi: 10.3389/fpls.2014.00342.

LAUGHTON, A.M., et al. The ontogeny of immunity in the honey bee, Apis mellifera L. following an immune challenge. Journal of insect physiology, v.57, 1023-1032, 2011. Available from: $<$ https://doi.org/10.1016/j.jinsphys.2011.04.020>. Accessed: Dec. 02, 2018. doi: 10.1016/j.jinsphys.2011.04.020.

LAVINE, M.D.; STRAND, M.R. Insect hemocytes and their role in immunity. Insect biochemistry and molecular biology, v.32, p.1295-1309, 2002. Available from: <https://doi.org/10.1016/ S0965-1748(02)00092-9>. Accessed: Dec. 02, 2018. doi: 10.1016/ S0965-1748(02)00092-9.

LÓPEZ-URIBE, M.M., et al. Inducible versus constitutive social immunity: examining effects of colony infection on glucose oxidase and defensin-1 production in honeybees. Royal Society open science, v.4, 170224, 2017. Available from: <https://www. ncbi.nlm.nih.gov/pmc/articles/PMC5451834/>. Accessed: Dec. 02, 2018. doi: 10.1098/rsos.170224
MAZZEI, M., et al. Infectivity of DWV associated to flower pollen: Experimental evidence of a horizontal transmission route. PLoS one, v.9, p.1-16, 2014. Available from: <https://doi.org/10.1371/ journal.pone.0113448>. Accessed: Dec. 02, 2018. doi: 10.1371/ journal.pone. 0113448

MAZZEI, M., et al. Effect of 1,3-1,6ß-Glucan on Natural and Experimental Deformed Wing Virus Infection in Newly Emerged Honeybees (Apis mellifera ligustica). PLoS one, v.11, e0166297, 2016. Available from: <https://doi.org/10.1371/journal. pone.0166297>. Accessed: Dec. 02, 2018. doi: 10.1371/journal. pone. 0166297

NAKHLEH, J., et al. The melanization response in insect immunity. Advances in Insect Physiology, v.52, p. 83-109, 2017. Available from: <https://doi.org/10.1016/bs.aiip.2016.11.002>. Accessed: Dec. 02, 2018. doi: 10.1016/bs.aiip.2016.11.002.

NAZZI, F.; PENNACCHIO, F. Disentangling multiple interactions in the hive ecosystem. Trends in parasitology, v.30, p.556-561, 2014. Available from: <https://doi.org/10.1016/j.pt.2014.09.006>. Accessed: Dec. 02, 2018. doi: 10.1016/j.pt.2014.09.006.

NEGRI, P., et al. Cellular immunity in Apis mellifera: studying hemocytes brings light about bees skills to confront threats. Apidologie, v.47, p.379-388, 2016. Available from: <https://link. springer.com/article/10.1007/s13592-015-0418-2>. Accessed: Accessed: Dec. 02, 2018. doi: 10.1007/s13592-015-0418-2.

NEGRI, P. et al. Apis mellifera hemocytes generate increate amounts of nitric oxide in response to wounding/encapsulation. Apidologie, v.45, p.610-617, 2014. Available from: <https://hal. archives-ouvertes.fr/hal-01234761/document>. Accessed: Dec. 02, 2018. doi: 10.1007/s13592-014-0279-0.

SABCALIU, A. et al. Biochemical and cytological Investigations n haemolymph of Apis mellifera Carpathica Bee in stressfulconditions. Bulletin of University of Agricultural Sciences and Veterinary Medicine Cluj-Napoca. Animal Science and Biotechnologies, v.67, p.313-320, 2010. Available from: <http://journals.usamvcluj. ro/index.php/zootehnie/article/view/5317/4744>. Accessed: Dec. 02, 2018. doi: 10.15835/buasvmen-asb:67:1-2:5317.

SAS INSTITUTE. JMP Statistics and Graphics Guide. SAS Institute Inc., Cary, NC, USA, 2008.

SCHMID, M.R. Adult honeybees (Apis mellifera L.) abandon hemocytic, but not phenoloxidase-based immunity. Journal of Insect Physiology, v.54, p.439-444, 2008. Available from: $<$ https://doi.org/10.1016/j.jinsphys.2007.11.002>.Accessed: Dec. 02, 2018. doi: 10.1016/j.jinsphys.2007.11.002.

SCHMID-HEMPEL, P. Evolution ecology of insect immune defenses. Annual Review of Entomology, v.50, p.529-551, 2005. Available from: <https://www.annualreviews.org/doi/pdf/10.1146/ annurev.ento.50.071803.130420>. Accessed: Dec. 02, 2018. doi: 10.1146/annurev.ento.50.071803.130420.

SHEEHAN, G. et al. Innate humoral immune defences in mammals and insects: the same, with differences?. Virulence, v.9, p.1625-1639, 2018. Available from: <https://doi.org/10. 1080/21505594.2018.1526531>. Accessed: Dec. 02, 2018. doi: $10.1080 / 21505594.2018 .1526531$.

SIVA-JOTHY, M.T., et al. Insect immunity: an evolutionary ecology perspective. Advances in insect physiology, v.32, p.1-48, 2005.

Ciência Rural, v.49, n.2, 2019. 
Available from: $<$ https://doi.org/10.1016/S0065-2806(05)32001-7>. Accessed: Dec. 02, 2018. doi: 10.1016/S0065-2806(05)32001-7.

SZYMAŚ, B.; JĘDRUSZUK, A. The influence of different diets on haemocytes of adult worker honey bees, Apis mellifera. Apidologie, v.34, p.97-102, 2003. Available from: <https:// doi.org/10.1051/apido:2003012>. Accessed: Dec. 02, 2018. doi: 10.1051/apido:2003012.

VAN WETTERE, A.; LEWBART, G.A. Cytologic diagnosis of diseases of invertebrates. Veterinary Clinics: Exotic Animal Practice, v.10, p.235-254, 2007. Available from: <https://doi org/10.1016/j.cvex.2006.11.003>. Accessed: Dec. 02, 2018. doi: 10.1016/j.cvex.2006.11.003.
WILSON-RICH, N. et al. Genetic, individual, and group facilitation of disease resistance in insect societies. Annual Review of Entomology, v.54, p.405-423, 2009. Available from: $<$ https://www.annualreviews.org/doi/pdf/10.1146/annurev. ento.53.103106.093301>. Accessed: Dec. 02, 2018. doi: 10.1146/ annurev.ento.53.103106.093301.

ZUFELATO, M.S. et al. Phenoloxidase activity in Apis mellifera honey bee pupae, and ecdysteroid-dependent expression of the prophenoloxidase mRNA. Insect Biochemistry and Molecular Biology, v.34, p.1257-1268, 2004. Available from: <https://doi. org/10.1016/j.ibmb.2004.08.005>. Accessed: Dec. 02, 2018. doi: 10.1016/j.ibmb.2004.08.005. 